\title{
AKURASI
}

p-ISSN : 2720-9067

e-ISSN : 2685-1059

Program Studi Magister Akuntansi

Fakultas Gkonomi dan Bisnis

Universitas Mataram

\section{KETERLIBATAN DEWAN KOMISARIS DALAM KOMITE TATA KELOLA PERUSAHAAN TERHADAP MANAJEMEN LABA DENGAN KEAHLIAN AKUNTANSI SEBAGAI VARIABEL MODERASI}

\author{
Siti Muskabikhul Khasanah ${ }^{1}$, Dwi Marlina Wijayanti ${ }^{2}$, Slamet Haryono ${ }^{3}$ \\ UIN Sunan Kalijaga Yogyakartal ${ }^{132}$ \\ ${ }^{2}$ Corresponding author: dwi.wijayanti@uin-suka.ac.id
}

\section{INFORMASI ARTIKEL}

Article history:

Dikirim tanggal: 10/09/2021

Revisi pertama tanggal: 18/09/2021

Diterima tanggal: 03/11/2021

Tersedia online tanggal 27/12/2021

\section{ABSTRAK}

Tujuan penelitian ini adalah untuk menguji keterlibatan dewan komisaris sebagai ketua maupun anggota biasa di dalam komite nominasi, komite remunerasi, dan komite audit terhadap praktik manajemen laba yang dimoderasi oleh keahlian akuntansi anggota dewan komisaris. Data yang digunakan adalah laporan keuangan dari perusahaan manufaktur yang terdaftar di BEI pada tahun 2015 sampai dengan 2019. Hasil penelitian menunjukkan bahwa dewan komisaris yang terlibat dalam komite nominasi dan komite remunerasi signifikan dapat mengurangi praktik manajemen laba tetapi tidak berpengaruh signifikan apabila dewan komisaris terlibat dalam komite audit. Hasil lain menunjukkan bahwa dewan komisaris yang memiliki keahlian akuntansi memoderasi hubungan antara komite nominasi dan remunerasi terhadap manajemen laba, tetapi tidak demikian dengan komite audit. Implikasi penelitian ini menekankan pentingnya mengatur komposisi komite-komite dalam keanggotaan dewan komisaris sebagai bentuk penguatan tata kelola perusahaan untuk mengurangi praktik manajemen laba.

Kata Kunci: manajemen laba, dewan komisaris, komite, keahlian akuntansi

\section{ABS T RACT}

The purpose of this study was to examine the involvement of the board of commissioners as chairman and ordinary members in the nomination committee, remuneration committee, and audit committee on earnings management practices moderated by the accounting expertise of members of the board of commissioners. The data used are financial reports from manufacturing companies listed on the IDX from 2015 to 2019. The results show that the board of commissioners involved in the nomination committee and remuneration committee significantly can reduce earnings management practices but has no significant effect if the board of commissioners is involved in the audit committee. Other results show that the board of commissioners with accounting expertise moderate the relationship between the nomination and remuneration committees on earnings management, but not with the audit committee. The implications of this study emphasize the importance of regulating the composition of the committees in the board of commissioners as a form of strengthening corporate governance to reduce earnings management practices.

Keywords: earnings management, board of commissioners, committee, accounting expertise 


\section{Pendahuluan}

Manajemen laba menjadi pusat perhatian besar di antara praktisi-praktisi akuntansi. Banyak skandal akuntansi besar yang sebelumnya sudah menyoroti masalah tersebut. Manajemen laba dapat dikatakan mirip dengan penipuan karena menyesatkan investor dalam menilai kinerja suatu perusahaan (Al-absy, Nor, \& Ku, 2019). Masalah manajemen laba perlu mendapat perhatian lebih karena mempengaruhi proses pengambilan keputusan oleh semua pemangku kepentingan perusahaan, termasuk investor, regulator, dan analis (Reguera-alvarado, Fuentes, \& Laffarga, 2019). Stakeholder perlu memahami bahwa manajemen laba dapat menurunkan keandalan laba (Khosheghbal, Amiri, \& Homayoon, 2017) dengan mengubah hasil pendapatan dalam laporan keuangan. Semakin rendah keandalan suatu pelaporan, semakin rendah pula data perusahaan yang bermanfaat (Khosheghbal, Amiri, \& Homayoon, 2017). Manajemen laba diidentifikasi sebagai intervensi yang sengaja dalam sistem pelaporan keuangan untuk mendapatkan keuntungan pribadi (Saona, 2019).

Rendahnya kualitas laporan keuangan akibat adanya manajemen laba disebabkan oleh tata kelola yang kurang baik dalam perusahaan (Shubita, 2020). Oleh karena itu, perusahaan harus memiliki mekanisme pengelolaan perusahaan yang efektif guna melindungi hak para pemangku kepentingan. Disamping itu, tata kelola yang baik di perusahaan juga dapat mengendalikan penyimpangan atau pelanggaran penyampaian dalam menginformasikan keuangan perusahaan. Manajemen laba adalah hal yang sulit dihindari karena merupakan dasar akrual dari penyusunan laporan keuangan perusahaan (Sunardi 2018). Manajer berperan dalam pemilihan kebijakan sesuai dengan standar akuntansi keuangan, maka wajar apabila kebijakan-kebijakan yang diterapkan digunakan untuk memaksimalkan keuntungan pada dirinya dan juga perusahaan.

Studi mengenai manajemen laba menjadi subjek penelitian baru yang banyak diteliti dalam bidang ekonomi keuangan khususnya akuntansi (Syahirah \& Mohd, 2017). Tetapi, hasil penelitian-penelitian sebelumnya menunjukkan hasil yang tidak konsisten. Al-absy, Nor, \& Ku (2017) menemukan bahwa perbedaan penelitian disebabkan oleh beberapa faktor moderasi. Penelitian Al-absy, Nor, \& Ku (2019) merekomendasikan keahlian akuntansi untuk menjadi mediator dalam membahas hubungan tata kelola perusahaan dengan manajemen laba. Oleh karena itu, penelitian ini mengisi kesenjangan dan menindaklanjuti saran dari hasil penelitian-penelitian sebelumnya.

Selama beberapa tahun, isu-isu yang berkaitan dengan manipulasi akuntansi dan transparansi informasi akuntansi telah menarik perhatian para peneliti dan praktisi akuntansi (Bouaziz, 2020). Salah satunya adalah dewan direksi. Board of directors dipandang sebagai bagian penting dari struktur tata kelola perusahaan yang dibebani tugas ganda (Al-dhamari, 2020). Dewan sering mendelegasikan beberapa tugas ke komite yang berbeda di dalam perusahaan karena hal itu mewakili pemisahan fungsi. Oleh karena itu, semakin besar dewan atau semakin banyak jumlah orang dalam keanggotaan dewan, semakin baik efek pencegahan manajemen laba (Saona, 2019). Al-sayani, Naimi, \& Afza, (2020) menyebutkan bahwa susunan dewan merupakan bagian dari tata kelola perusahaan yang diharapkan dapat mengurangi praktik manajemen laba.

Kehadiran dewan komisaris dalam satu atau lebih komite dewan dapat mencerminkan bahwa dewan komisaris mencoba untuk mendominasi keseluruhan 
mekanisme Corporate Governance di suatu perusahaan, terutama di perusahaan dengan kontribusi orang dalam yang tinggi (Al-absy, Nor, \& Ku, 2019). Banyak dewan komisaris yang merangkap sebagai komite nominasi, remunerasi dan komite audit. Dominasi ketua dewan komisaris atas komite nominasi (NC), komite remunerasi (RC), dan komite audit (AC) telah menjadi masalah penting, khususnya ketika direktur suatu perusahaan adalah orang dalam yang akan mendominasi kebijakan pemilihan dan kompensasi direktur. Padahal, independensi diperlukan antara pihak pengelola perusahaan dengan pemilik saham maupun dewan komisaris dari kalangan keluarga ataupun orang dalam (Syahirah \& Mohd, 2017).

Al-absy, Nor, \& Ku (2019) dalam penelitiannya menemukan bahwa ketua dari dewan komisaris yang berpartisipasi atau menjadi bagian dari komite nominasi, cenderung terlibat dalam manajemen laba, baik sebagai ketua maupun anggota biasa. Hal ini didasari oleh pendapat bahwa tujuan komite nominasi adalah agar proses pemilihan atau penunjukan direktur menjadi profesional dan agar terhindar dari intervensi oleh CEO maupun ketua dewan. Padahal, komite nominasi juga diyakini dapat membuat dewan komisaris menjadi efektif dengan cara pengelolaan komposisi, sebagai contoh adalah meningkatkan independensi dan kualifikasi dewan (Chaudhry, Roomi, \& Aftab, 2020). Selain komite nominasi, hasil penelitian Al-absy, Nor, \& Ku (2019) juga menemukan bahwa dewan komisaris yang juga merupakan ketua maupun anggota dari komite remunerasi tidak ada pengaruhnya terhadap praktik manajemen laba. Tujuan komite remunerasi adalah untuk memberikan dukungan dan saran kepada dewan mengenai masalah anggota dewan remunerasi (Kanapathippillai, Johl, \& Wines, 2016).

Selain terlibat dalam komite nominasi dan remunerasi, dewan komisaris yang terlibat dalam komite audit juga mempengaruhi manajemen laba. Reguera-alvarado, Fuentes, \& Laffarga (2019) menyebutkan bahwa spesialisasi auditor penting dalam memitigasi manajemen laba. Penelitian sebelumnya menunjukkan bahwa ukuran dari dewan komisaris tidak ada hubungan yang signifikan dengan manajemen laba, begitu pula dengan hubungan antara komite audit dan manajemen laba (Khosheghbal, Amiri, \& Homayoon, 2017). Komite audit yang aktif, berfungsi dengan baik, dan terstruktur dengan baik memiliki lebih banyak cara langsung untuk mengendalikan manajemen laba. Tetapi hasil lain menunjukkan bahwa dewan komisarisnya terlibat dalam komite audit lebih cenderung mempraktikkan manajemen laba (Al-absy, Nor, \& Ku, 2017). Namun demikian, penelitian lain mengenai komite audit dengan manajemen laba memberikan hasil bahwa antara kedua variabel tersebut tidak berhubungan secara signifikan (Khosheghbal, Amiri, \& Homayoon, 2017). Beberapa penelitian lainnya belum menetapkan hubungan yang pasti antara mekanisme komite audit dan manajemen laba, oleh karena itu diperlukan lebih banyak penelitian (Chandrasegaram, Rahimansa, \& Rahman, 2013).

Berdasarkan perbedaan hasil oleh penelitian-penelitian sebelumnya, penelitian ini akan memperdalam analisis mengenai ketua dewan komisaris yang juga merupakan komite audit dalam akan mempengaruhi praktik manajemen laba ataukah tidak. Al-absy, Nor, \& $\mathrm{Ku}$ (2017) menemukan bahwa perbedaan penelitian disebabkan oleh beberapa faktor seperti kepemilikan keluarga dan keahlian akuntansi ketua dewan komisaris atau ketua dewan audit. Penelitian tersebut mengharapkan agar studi di masa depan mempertimbangkan faktor-faktor yang dapat memoderasi hubungan antara dewan 
komisaris yang sekaligus merupakan ketua maupun anggota biasa dari komite audit. Originalitas penelitian ini adalah menjustifikasi penggunaan teori agensi sebagai dasar penentuan hubungan antar variabel. Sebagian besar penelitian sebelumnya menjelaskan bahwa keterlibatan dewan komisaris dalam komite nominasi, remunerasi, dan audit dapat meningkatkan manajemen laba. Padahal, manajemen laba dapat diminimalisasi jika prinsipal juga memiliki kewenangan di dalam perusahaan.

Keahlian akuntansi direkomendasikan menjadi variabel moderasi (Al-absy, Nor, \& $\mathrm{Ku}, 2019)$. Penelitian sebelumnya menemukan bahwa keahlian akuntansi anggota dewan komisaris serta keahlian keuangan dewan komisaris mempunyai pengaruh negatif terhadap praktik manajemen laba di perusahaan (Dwiharyadi, 2017). Hasil ini membuktikan bahwa ketika ada interaksi antara dewan-komisaris yang memiliki keahlian akuntansi sekaligus keuangan, dewan komisaris selaku pihak yang memonitoring atau melakukan pemeriksaan atas laporan keuangan akan berfungsi secara efektif. Oleh karena itu, penelitian ini bertujuan untuk menguji keterlibatan dewan komisaris sebagai ketua maupun anggota biasa di dalam komite nominasi, komite remunerasi, dan komite audit terhadap praktik manajemen laba yang dimoderasi oleh keahlian akuntansi anggota dewan komisaris.

\section{Kerangka Teoretis Dan Pengembangan Hipotesis}

Munculnya praktik manajemen laba dapat dijelaskan oleh teori keagenan (Al-absy, Nor, \& Ku, 2017). Manajemen laba dalam teori keagenan dipengaruhi oleh konflik kepentingan yang terjadi antara pemilik dan pengelola, dan ini terjadi ketika masingmasing pihak berusaha untuk memaksimalkan kemakmuran yang diharapkan (Sunardi, 2018). Secara konseptual, teori keagenan adalah adanya hubungan antara pemilik perusahaan, dan pemilik mendelegasikan pekerjaannya kepada agennya (Kharashgah et al., 2019). Teori keagenan menunjukkan bahwa dipisahnya pemilik dan pengontrol perusahaan mengarah pada perbedaan antara kepentingan manajer dan pemilik/pemegang perusahaan (Manuel \& Martin, 2018). Hal inilah yang menjadi sumber masalah keagenan, yang menunjukkan adanya konflik kepentingan di antara manajer dan pemegang saham.

Konflik keagenan muncul ketika pengelolaan suatu perusahaan terlepas dari kepemilikannya. Pemilik atau principal memberi wewenang kepada dewan komisaris dan dewan direksi untuk mengelola operasi perusahaan dan membuat keputusan atas nama pemilik. Dengan kata lain, kepentingan manajemen dan pemilik berbeda. Meningkatnya konflik kepentingan karena pemilik tidak melakukan pemantauan aktivitas sehari-hari manajer untuk memastikan bahwa manajer bertindak sesuai dengan dengan harapan pemegang saham (Panda \& Leepsa, 2017). Teori keagenan menyarankan good governance yang efektif untuk menurunkan manajemen laba dengan membentuk komite yang sesuai dan dewan direksi yang sesuai sebagai mekanisme tata kelola perusahaan yang penting (Chaudhry, Roomi, \& Aftab, 2020). Penelitian Al-absy, Nor, \& Ku (2019) menyarankan bahwa mekanisme tata kelola perusaaan misalnya dewan direksi, kepemilikan perusahaan dan komite audit dapat mengurangi manajemen laba serta masalah keagenan.

Manajemen laba dapat dilihat sebagai biaya agensi potensial karena manajer memanipulasi laba untuk menyesatkan pemegang saham dan memenuhi kepentingannya sendiri (Al-absy, Nor, \& Ku, 2019). Oleh karena itu, dewan direksi harus memainkan peran penting dalam membatasi tingkat manajemen laba. Salah satu bentuk manipulasi 
laba yang dapat mengurangi atau menurunkan keandalan laba adalah manajemen laba. Semakin rendah keandalan pendapatan, semakin rendah data perusahaan yang bermanfaat (Khosheghbal, Amiri, \& Homayoon, 2017). Manajemen laba memengaruhi proses pengambilan keputusan dari semua pemangku kepentingan perusahaan, termasuk investor, regulator, dan analis (Reguera-alvarado, Fuentes, \& Laffarga, 2019).

Praktik tata kelola perusahaan berbeda antar negara dan penyebarannya pun beragam tergantung dengan evolusi sistem keuangan yang berbeda (Zubeltzu-jaka, Alvarezetxeberria, \& Ortas, 2020). Komite dewan sebuah perusahaan merupakan instrumen penting untuk melindungi pemangku kepentingan dan memaksimalkan kekayaan pemegang saham (Chaudhry, Roomi, \& Aftab, 2020). Komite tersebut adalah komite nominasi, komite remunerasi, dan komite audit. Komite nominasi adalah komite yang bertanggungjawab atas pemilihan calon anggota dewan dan penilaian anggota dewan yang ada (Al-absy, Nor, \& Ku, 2019). Tanggung jawab komite nominasi juga tentang pemilihan CEO perusahaan yang selanjutnya bertanggung jawab atas kegiatan operasional perusahaan (Chaudhry, Roomi, \& Aftab, 2020). Tata kelola perusahaan biasanya merekomendasikan dewan membentuk komite nominasi untuk memilih anggota yang baru. Komite nominasi diyakini dapat membuat dewan komisaris menjadi efektif dengan cara pengelolaan komposisi, sebagai contoh adalah meningkatkan independensi dan kualifikasi dewan (Chaudhry, Roomi, \& Aftab, 2020). Tujuan komite nominasi adalah agar proses pemilihan direktur menjadi professional serta menghindari intervensi dari CEO atau ketua dewan komisaris yang berlebihan (Ahmad et al., 2018).

Berdasarkan teori agensi, konflik kepentingan yang muncul antara agen dan prinsipal ketika masing-masing pihak berupaya untuk memaksimalkan keuntungan yang diinginkan akan mempengaruhi manajemen laba (Sunardi, 2018). Secara konsep, teori keagenan adalah bahwa ada hubungan antara pemegang saham dan manajer, di mana pemilik mendelegasikan pekerjaannya kepada agennya (Kharashgah et al., 2019). Berdasarkan hasil penelitian sebelumnya menemukan bahwa komite nominasi yang dewan komisaris terlibat di dalamnya berpengaruh negatif terhadap praktik manajemen laba (Liu, Harris, \& Omar, 2013). Dengan demikian dapat diargumentasikan bahwa keterlibatan dewan komisaris dalam keanggotaan komite remunerasi dapat mengurangi praktik manajemen laba sehingga diajukan hipotesis sebagai berikut:

$\mathrm{H}_{1}$ : Dewan komisaris yang terlibat dalam komite nominasi akan berpengaruh negatif terhadap praktik manajemen laba

Penelitian Al-absy, Nor, \& Ku (2019) menjelaskan bahwa terlibatnya dewan komisaris sebagai ketua maupun anggota biasa dalam komite remunerasi berpengaruh terhadap praktik manajemen laba, tetapi tidak demikian apabila anggota dewan komisaris yang hanya terlibat dalam komite remunerasi. Penelitian Al-hadrami, Rafiki, \& Sarea (2020) menunjukkan bahwa kualitas komite remunerasi dipengaruhi oleh independensi komite remunerasi. Penelitian sebelumnya juga mengungkapkan bahwa komite remunerasi merupakan mekanisme tata kelola perusahaan yang efektif (Kanapathippillai, Johl, \& Wines, 2016). Maka berdasarkan teori agensi, konflik kepentingan yang timbul antara agen dan prinsipal ketika masing-masing pihak berupaya untuk memaksimalkan kemakmuran yang diinginkan dapat berpengaruh terhadap manajemen laba (Sunardi, 2018). Teori 
keagenan menggambarkan bahwa ada hubungan antara prinsipal (pemegang saham) dan agen (pengelola perusahaan), di mana pemilik mendelegasikan pekerjaannya kepada agennya (Kharashgah et al., 2019).

Sebagian besar tata kelola perusahaan di dunia mengharuskan perusahaan untuk membentuk komite remunerasi. Penelitian Ahmad et al. (2018) menemukan bahwa keberadaan komite remunerasi sangat penting dalam memutuskan apakah akan memberikan pengungkapan sukarela atas tindakan remunerasi, begitu pula dengan kualitas komite remunerasi. Analisis selanjutnya menemukan bahwa ketekunan dan independensi yang dimiliki oleh komite remunerasi dapat meningkatkan kualitas dari komite remunerasi. Penelitian sebelumnya juga mengungkapkan bahwa mekanisme tata kelola perusahaan yang efektif ada pada komite remunerasi (Kanapathippillai, Johl, \& Wines, 2016). Di Negara lain, beberapa perusahaan memperbolehkan ketua dewan komisaris menjadi anggota komite remunerasi, seperti di Negara Inggris (Al-absy, Nor, \& Ku, 2019). Berdasarkan hasil penelitian sebelumnya dapat diargumentasikan bahwa dewan komisaris yang ada di dalam komite remunerasi dapat mengurangi praktik manajemen laba sehingga diajukan hipotesis dalam penelitian sebagai berikut:

$\mathrm{H}_{2}$ : Dewan komisaris yang terlibat dalam komite remunerasi akan berpengaruh negatif terhadap praktik manajemen laba

Skandal akuntansi dan kegagalan perusahaan, seperti Enron, WorldCom dan Toshiba, telah mendorong regulator untuk melihat pentingnya dan peran komite audit dalam mempraktikkan manajemen laba. Kemandirian komite audit diakui sebagai salah satu faktor utama yang meningkatkan efektivitas komite audit (Al-sayani, Naimi, \& Afza, 2020). Independensi yang dimiliki komite audit sangat penting bagi auditor karena apabila terjadi perselisihan dengan manajemen, auditor akan menerima dukungan dari komite audit. Kemudian diasumsikan bahwa semakin tinggi tingkat kompetensi komite audit, semakin kualitatif pula pelaporan keuangan yang diberikan dan tentunya berdampak positif bagi investor yang akan mengambil keputusan (Al-hadrami, Rafiki, \& Sarea, 2020). Penelitian sebelumnya mengemukakan bahwa mekanisme corporate governance, misalnya dewan direksi, kepemilikan dan komite audit, dapat mengurangi masalah keagenan dan manajemen laba (Susanto, 2016). Dengan adanya komite audit yang aktif, berfungsi dengan baik, dan terstruktur dengan baik mungkin memiliki lebih banyak cara langsung untuk mengendalikan manajemen laba (Chandrasegaram, Rahimansa, \& Rahman, 2013). Fungsi komite audit adalah untuk memantau kinerja keuangan dan pelaporan keuangan perusahaan (Lin \& Hwang, 2010).

Penelitian Al-absy, Nor, \& Ku (2017) menemukan bahwa perusahaan yang dewan komisarisnya terlibat dalam komite audit lebih cenderung mempraktikkan manajemen laba. Penelitian tersebut juga menemukan hasil serupa ketika keterlibatan ketua dewan komisaris hanya sebagai anggota biasa komite audit. Namun demikian, ketua dewan komisaris yang juga merupakan ketua komite audit tidak terkait dengan manajemen laba. Penelitian lain mengenai komite audit dengan manajemen laba menemukan tidak ada hubungan yang signifikan antara komite audit dan manajemen laba (Khosheghbal, Amiri, \& Homayoon, 2017). Oleh karena itu, investor disarankan untuk tidak menjadikan komite audit sebagai kriteria manajemen laba. Dengan demikian dapat diargumentasikan bahwa keterlibatan 
dewan komisaris dalam komite audit dapat mengurangi praktik manajemen laba, sehingga diajukan hipotesis sebagai berikut:

$\mathrm{H}_{3}$ : Dewan komisaris yang terlibat dalam komite audit akan berpengaruh negatif terhadap praktik manajemen laba

Keahlian akuntansi merupakan keahlian yang berkaitan dengan kebijakan akuntansi serta siklus dari laporan keuangan secara langsung (Hariani, Diana, \& Mawardi, 2020). Dengan menjalankan prinsip good corporate governance adalah cara meminimalisir praktik manajemen laba yang dilakukan oleh manajer (Hariani, Diana, \& Mawardi, 2020). Kehadiran dewan komisaris yang berperan dalam mengawasi manajemen serta komite audit yang mengawasi proses pelaporan keuangan serta merupakan salah satu mekanisme pengelolaan perusahaan yang efektif (Dwiharyadi, 2017). Dewan komisaris harus menjalankan tata kelola perusahaan yang baik karena bertanggungjawab untuk memberi nasihat dan mengawasi direksi sehubungan dengan kinerja perusahaan terhadap pemegang saham (Sari, 2017). Efektivitas dewan komisaris dapat membatasi adanya praktik manajemen laba (Lestari \& Murtanto, 2017). Oleh karena itu, untuk mengetahui dan memahami pelaporan keuangan perusahaan, keahlian di bidang keuangan maupun akuntansi harus dimiliki oleh dewan komisaris, sehingga pemegang saham menerima informasi yang dapat dipercaya dari manajemen (Hariani, Diana, \& Mawardi, 2020).

Penelitian sebelumnya menemukan hasil yang beragam. Hariani, Diana, \& Mawardi (2020) menemukan bahwa keahlian akuntansi yang dimiliki dewan komisaris berpengaruh secara simultan terhadap manajemen laba. Penelitian Al-absy, Nor, \& Ku (2017) menemukan bahwa perusahaan yang dewan komisarisnya terlibat dalam komite audit lebih cenderung mempraktikkan manajemen laba, termasuk jika keterlibatan ketua dewan komisaris hanya sebagai anggota biasa komite audit. Namun hasil studi lainnya menyatakan bahwa ketua dewan komisaris yang juga merupakan ketua komite audit tidak terkait dengan manajemen laba (Susanto, 2016). Studi yang berbeda menunjukkan bahwa keterlibatan ketua dewan dalam komite audit, baik sebagai ketua maupun anggota akan mengurangi efektivitas komite audit (Al-absy, Nor, \& Ku, 2017). Penelitian lain mengenai komite audit dengan manajemen laba menemukan tidak ada hubungan yang signifikan antara komite audit dan manajemen laba (Khosheghbal, Amiri, \& Homayoon, 2017) sehingga investor disarankan untuk tidak menjadikan komite audit sebagai kriteria manajemen laba. Namun penelitian lain menemukan bahwa keahlian akuntansi anggota dewan komisaris dan keahlian keuangan dari dewan komisaris memiliki pengaruh negatif terhadap praktik manajemen laba perusahaan (Dwiharyadi, 2017). Hasil ini memberikan bukti bahwa fungsi dewan komisaris sebagai pihak yang melakukan monitoring atas laporan keuangan akan dapat berjalan dengan baik ketika terdapat interaksi antara dewan komisaris yang memiliki keahlian akuntansi dengan dewan komisaris yang memiliki kemampuan keuangan. Dengan demikian dapat diargumentasikan bahwa keahlian akuntansi dapat memoderasi dewan komisaris yang terlibat dalam komite nominasi, komite remunerasi dan komite audit dalam memengaruhi praktik manajemen laba sehingga dirumuskan hipotesis sebagai berikut:

$\mathrm{H}_{4}$ : Dewan komisaris yang terlibat dalam komite nominasi berpengaruh negatif terhadap praktik manajemen laba, dengan keahlian akuntansi sebagai variabel moderasi. 
H5: Dewan komisaris yang terlibat dalam komite remunerasi berpengaruh negatif terhadap praktik manajemen laba, dengan keahlian akuntansi sebagai variabel moderasi.

$\mathrm{H}_{6}$ : Dewan Komisaris yang terlibat dalam komite audit berpengaruh negatif terhadap praktik manajemen laba, dengan keahlian akuntansi sebagai variabel moderasi

\section{Metode Penelitian}

Penelitian ini merupakan penelitian kuantitatif dengan unit analisis adalah laporan keuangan perusahaan manufaktur tahun 2015 sampai dengan 2019. Pengambilan sampel dalam penelitian ini menggunakan metode purposive sampling dengan kriteria sebagai berikut: (1) perusahaan manufaktur yang terdaftar di Bursa Efek Indonesia (BEI) pada periode 2015-2019; (2) laporan tahunan perusahaan tersedia lengkap tahun 2015-2019; (3) perusahaan memiliki daftar komite nominasi, komite remunerasi, dan komite audit serta (4) memiliki data lengkap yang diperlukan dalam penelitian. Dengan kriteria tersebut jumlah sampel yang memenuhi kriteria sebanyak 92 perusahaan dengan 460 observasi.

Penelitian ini menggunakan variabel dependen berupa manajemen laba. Manajemen laba dalam penelitian ini dihitung menggunakan Model Jones (1991) yang mengestimasi descretionary accruals (DA) yang berisi karakteristik akrual yang berasal dari oportunisme manajemen. Untuk mengukur manajemen laba digunakan model berikut:

$\frac{T A C_{i t}}{T A_{i t-1}}=+\beta_{1}\left(\frac{1}{T A_{i t-1}}\right)+\beta_{2}\left(\frac{\Delta S_{t}}{T A_{i t-1}}\right)+\beta_{3}\left(\frac{P P E_{i t}}{T A_{i t-1}}\right)+\varepsilon_{i t}$

Keterangan:

$\mathrm{TAC}_{\mathrm{it}}$ : penghasilan sebelum pos luar biasa dikurangi arus kas dari operasi;

$\mathrm{TA}_{\mathrm{it}-1:}$ total aset dalam satu tahun terakhir;

$\Delta \mathrm{S}_{\mathrm{t}}: \quad$ pendapatan di tahun $\mathrm{t}$ dikurangi pendapatan di tahun ke-1;

PPE: Properti bruto, pabrik, dan peralatan di tahun t;

$\varepsilon_{\text {it: }} \quad$ syarat kesalahan regresi.

Penelitian ini menggunakan beberapa variabel independen berupa komite nominasi, komite remunerasi, dan komite audit. Dewan komisaris yang terlibat dalam komite nominasi diberi angka 1 dan sebaliknya, jika dewan komisaris tidak terlibat dalam komite nominasi maka diberi angka 0 . Begitu juga dengan dewan komisaris yang terlibat dalam komite remunerasi diberi angka 1 dan sebaliknya diberi angka 0 . Terakhir, dewan komisaris yang terlibat dalam komite audit diberi angka 1 dan sebaliknya juga diberi angka 0 . Variabel moderasi dalam penelitian ini adalah keahlian akuntansi dewan komisaris, yang diukur diukur dengan menggunakan rasio dewan komisaris yang memiliki keahlian keuangan terhadap jumlah dewan komisaris dalam perusahaan merujuk pada penelitian Dwiharyadi (2017).

$$
\mathrm{KA}=\frac{x}{y}
$$

Keterangan:

$$
\begin{aligned}
\mathrm{KA} & =\text { rasio dewan komisaris; } \\
\mathrm{X} & =\text { dewan komisaris yang memiliki keahlian akuntansi; } \\
\mathrm{Y} & =\text { jumlah dewan komisaris. }
\end{aligned}
$$


Penelitian ini menggunakan beberapa variabel kontrol berupa ukuran perusahaan (FSIZE), return on Assets (ROA), dan financial leverage (LEV). Analisis regresi berganda digunakan untuk menguji pengaruh keterlibatan dewan komisaris di dalam komite nominasi (BCNC), komite remunerasi (BCRC), dan komite audit (BCAC) terhadap manajemen laba (EM), dengan keahlian akuntansi dewan komisaris (KA) sebagai variabel moderasi. Model persamaan regresi untuk menguji hipotesis adalah sebagai berikut: $\mathrm{EM}=\beta_{0}+\beta_{1} \mathrm{BCNC}+\beta_{2} \mathrm{BCRC}+\beta_{3} \mathrm{BCAC}+\beta_{4} \mathrm{KA}+\beta_{5} \mathrm{FSIZE}+\beta_{6} \mathrm{ROA}+\beta_{7} \mathrm{LEV}+\varepsilon$

$\mathrm{EM}=\beta_{0}+\beta_{1} \mathrm{BCNC}+\beta_{2} \mathrm{BCRC}+\beta_{3} \mathrm{BCAC}+\beta_{4} \mathrm{KA}+\beta_{5} \mathrm{BCNC} * \mathrm{KA}+\beta_{6} \mathrm{BCRC} * \mathrm{KA}+\beta_{7} \mathrm{BCAC} * \mathrm{KA}+\varepsilon .$. (4)

\section{Hasil dan Pembahasan}

Sampel yang digunakan dalam penelitian ini adalah 92 perusahaan manufaktur yang terdaftar di Bursa Efek Indonesia (BEI) pada tahun 2015 sampai dengan 2019. Tabel 1 berikut menyajikan hasil statistik deskriptif dalam penelitian ini:

Tabel 1. Statistik Deskriptif

\begin{tabular}{lcccrr}
\hline Variabel & N & Minimum & Maximum & \multicolumn{1}{c}{ Mean } & \multicolumn{1}{c}{ Std. Dev. } \\
\hline EM & 460 & -0.296838 & 0.259726 & -0.009133 & 0.034261 \\
KA & 460 & 0.000000 & 1.000000 & 0.307064 & 0.188649 \\
\hline & & & Frekuensi & Persentase & \\
\hline \multirow{2}{*}{ BCNC } & \multirow{2}{*}{460} & 1 & 326 & $70,87 \%$ & \\
& & 0 & 124 & $29,13 \%$ & \\
BCRC & 460 & 1 & 343 & $74,57 \%$ & \\
& & 0 & 117 & $25,43 \%$ & \\
BCRC & 460 & 1 & 58 & $12,61 \%$ & \\
& & 0 & 402 & $87,39 \%$ & \\
\hline
\end{tabular}

Berdasarkan statistik deskriptif pada Tabel 1 dapat dijelaskan bahwa variabel dependen earnings management (EM) mempunyai nilai minimum sebesar -0,296838, nilai maximum 0,259726 dan rata-rata earnings management sebesar -0.009133. Hal ini menunjukkan bahwa nilai 0,259726 menunjukkan bahwa perusahaan memiliki potensi earnings management yang lebih tinggi dibanding dengan yang lainnya, dan angka -0,296838 menunjukkan bahwa perusahaan melakukan earnings management terendah di angka tersebut. Kemudian nilai mean EM sebesar $-0,009133$ berarti rata-rata perusahaan melakukan pola income minimization dalam pengelolaan laba. Variabel independen keterlibatan dewan komisaris di dalam komite nominasi (BCNC) menunjukkan jumlah $70,87 \%$, sedangkan dewan komisaris yang tidak terlibat dalam komite nominasi sebesar 29,13\%. Keterlibatan dewan komisaris di dalam komite remunerasi (BCRC) sebesar $74,57 \%$, sedangkan keterlibatan dewan komisaris dalam komite audit (BCAC) dalam persentase yang relatif rendah yaitu sebesar 12,61\%. Hal ini berarti sebanyak 87,39\% dewan komisaris tidak terlibat dalam komite audit. Variabel moderasi komite audit memiliki nilai maksimal 1,000 dan nilai minimum sebesar 0,00 serta nilai mean 0,3070 yang berarti bahwa 30,70\% komite audit memiliki keahlian akuntansi.

Hasil pengujian hipotesis dalam analisis regresi linier berganda menggunakan uji model random effect disajikan pada Tabel 2. Hasil uji signifikansi model secara simultan 
menunjukkan nilai probabilitas sebesar 0,000 dan nilai $\mathrm{F}$ test $=17,344$ yang menunjukkan model layak digunakan untuk memprediksi. Koefisien determinasi menggunakan Adjusted $R$ Square menunjukkan nilai 0,1995 yang berarti bahwa kemampuan model dalam menjelaskan pengaruh variabel independen terhadap variabel dependen adalah sebesar 19,95\%. Hasil uji signifikansi parameter individual pada tabel 2 menunjukkan bahwa variabel keterlibatan dewan komisaris dalam komite nominasi (BCNC) memiliki nilai probabilitas sebesar 0,0000 dengan koefisien regresi positif sebesar 0,030852 , nilai probabilitas tersebut menunjukkan angka yang lebih kecil dari $0,05(0,0000<0,05)$. Hal ini berarti bahwa variabel dewan komisaris yang terlibat dalam komite nominasi berpengaruh signifikan positif terhadap manajemen laba, sehingga dapat disimpulkan bahwa hipotesis 1 ditolak. Hasil ini Kontradiktif dengan hasil penelitian sebelumnya yang menyatakan bahwa dewan komisaris yang terlibat di dalam komite nominasi akan berpengaruh terhadap praktik manajemen laba (Al-absy, Nor, \& Ku 2019). Dewan komisaris adalah pengatur bagi komite nominasi sehingga keterlibatan dewan komisaris dalam komite nominasi meningkatkan efektivitas komite. Hal ini karena komite nominasi dipilih oleh dewan komisaris, sehingga segala peraturan yang dibuat oleh komite nominasi harus diketahui oleh dewan komisaris (Wasan, 2020). Dengan demikian, praktik manajemen laba bisa diantisipasi apabila ada intervensi dewan komisaris dalam komite nominasi.

Tabel 2. Hasil Analisis Regresi

\begin{tabular}{|c|c|c|c|c|c|}
\hline Variable & & Coefficient & Std. Error & t-Statistic & Prob. \\
\hline $\mathrm{C}$ & & 0.035637 & 0.024584 & 1.449606 & 0.1479 \\
\hline $\mathrm{BCNC}$ & & 0.030852 & 0.007052 & 4.374592 & 0.0000 \\
\hline BCRC & & -0.028591 & 0.007290 & -3.921753 & $0.0001 *$ \\
\hline $\mathrm{BCAC}$ & & -0.003558 & 0.003702 & -0.960946 & 0.3371 \\
\hline ROA & & 0.180179 & 0.013770 & 13.08520 & $0.0000 *$ \\
\hline FIRMSIZE & & -0.001503 & 0.000819 & -1.834688 & 0.0672 \\
\hline LEV & & 0.009309 & 0.002259 & 4.121419 & $0.0000 *$ \\
\hline KA & & -0.002249 & 0.006331 & -0.355203 & 0.7226 \\
\hline F test & $=17,344$ & & & & \\
\hline Sig. F test & $=0,000$ & & & & \\
\hline R Square & $=0,2117$ & & & & \\
\hline Adjusted R Square & $=0,1995$ & & & & \\
\hline
\end{tabular}

Hasil selanjutnya menunjukkan bahwa variabel keterlibatan dewan komisaris dalam komite remunerasi (BCRC) memiliki nilai probabilitas sebesar 0,0001 dengan koefisien regresi sebesar $-0,028591$, nilai probabilitas tersebut menunjukkan angka yang lebih kecil dari $0,05(0,0001<0,05)$. Hasil ini menunjukkan bahwa dewan komisaris yang terlibat dalam komite remunerasi berpengaruh signifikan negatif terhadap manajemen laba, sehingga dapat disimpulkan bahwa hipotesis kedua $\left(\mathrm{H}_{2}\right)$ diterima. Hasil penelitian ini menunjukkan bahwa perusahaan yang dewan komisarisnya terlibat sebagai ketua maupun anggota biasa pada komite remunerasi dapat mengurangi terjadinya praktik manajemen laba dapat didukung. Hasil ini sejalan dengan penelitian Al-absy, Nor, \& Ku (2019) yang menemukan bahwa anggota dewan komisaris yang hanya terlibat dalam komite remunerasi 
berpengaruh negatif dalam praktik manajemen laba. Komite remunerasi bertanggung jawab kepada dewan komisaris dan membantu dewan komisaris dalam menentukan remunerasi mereka sendiri yang nantinya diusulkan kepada para pemegang saham, sehingga ketua komite remunerasi atau anggotanya sebaiknya merupakan satu dari komisaris independen (Murwaningsari, 2006). Hasil penelitian ini tidak sejalan dengan penelitian Ramadhan (2016) yang menyatakan keanggotaan dalam dewan komisaris dalam komite remunerasi tidak berpengaruh positif signifikan terhadap manajemen laba.

Hasil pengujian pengaruh keterlibatan dewan komisaris dalam komite audit (BCAC) memiliki nilai probabilitas sebesar 0,3371 dengan koefisien regresi sebesar -0,003558, nilai probabilitas tersebut menunjukkan angka yang lebih besar dari $0,05(0,3371>0,05)$. Hal ini berarti bahwa variabel dewan komisaris yang terlibat dalam komite audit tidak berpengaruh signifikan negatif terhadap manajemen laba, sehingga dapat disimpulkan bahwa hipotesis ketiga $\left(\mathrm{H}_{3}\right)$ ditolak. Dengan demikian dewan komisaris yang terlibat dalam komite audit tidak berpengaruh signifikan terhadap manajemen laba. Hasil ini sejalan dengan penelitian Khosheghbal, Amiri, \& Homayoon (2017) yang menyatakan bahwa tidak ada hubungan yang signifikan antara komite audit dan manajemen laba. Oleh karena itu, investor disarankan untuk tidak menjadikan komite audit sebagai kriteria manajemen laba (Khosheghbal, Amiri, \& Homayoon, 2017). Argumentasi yang sejalan juga dinyatakan oleh Chandrasegaram, Rahimansa \& Rahman (2013) bahwa beberapa penelitian belum menetapkan hubungan yang pasti antara mekanisme komite audit dan manajemen laba, oleh karena itu diperlukan lebih banyak penelitian. Hasil pengujian terhadap variabel kontrol menunjukkan bahwa hanya profitabilitas dan leverage yang berpengaruh signifikan positif terhadap manajemen laba, sedangkan ukuran perusahaan berpengaruh negatif tidak signifikan terhadap manajemen laba.

Hasil pengujian moderasi dalam penelitian ini disajikan pada Tabel 3. Hasil uji $\mathrm{F}$ menunjukkan bahwa model signifikan dalam menjelaskan pengaruh variabel independen terhadap variabel dependen yang ditunjukkan oleh nilai signifikansi uji F sebesar 0,000 dan nilai $\mathrm{F}$ test $=18,935$. Adjusted $R$ Square sebesar 0,1899 menjelaskan koefisien determinasi yang menunjukkan kemampuan model dalam menjelaskan variasi dalam variabel independen sebesar $18,99 \%$, sedangkan sisanya $81,11 \%$ dipengaruhi oleh variabel di luar model penelitian yang dispesifikasikan. Hasil pengujian moderasi menunjukkan bahwa keahlian akuntansi memoderasi (M1) hubungan antara keterlibatan dewan komisaris dalam komite remunerasi (BCRC) dengan manajemen laba dengan nilai koefisien sebesar 0,036844 dan probabilitas 0,0138 yang berarti lebih kecil dari nilai alpha 0,05 . Hal ini berarti keahlian akuntansi memoderasi hubungan antara keterlibatan dewan komisaris dalam komite nominasi terhadap manajemen laba. Hasil ini mengindikasikan bahwa variabel moderasi keahlian akuntansi memperkuat hubungan antara dewan komisaris dalam komite remunerasi (BCRC) dengan manajemen laba, sehingga hipotesis keempat $\left(\mathrm{H}_{4}\right)$ diterima. Hasil penelitian membuktikan tentang pengaruh keahlian akuntansi dalam memoderasi hubungan antara keterlibatan dewan komisaris dalam komite nominasi terhadap manajemen laba. Hasil ini sejalan temuan penelitian Hariani, Diana, \& Mawardi (2020) yang menemukan bahwa keahlian akuntansi dewan komisaris berpengaruh terhadap praktik manajemen laba. Dewan komisaris diharapkan memiliki peran dalam meningkatkan kualitas laba dalam perusahaan dengan cara membatasi tingkat manajemen 
laba (Sari, 2017). Hal tersebut salah satunya dilakukan dengan cara monitoring atas laporan keuangan dan lain sebagainya. Dewan komisaris yang memiliki keahlian akuntansi serta terlibat di dalam komite nominasi sangat efektif dalam mencegah praktik manajemen laba dalam perusahaan.

Tabel 3. Hasil Pengujian Moderasi

\begin{tabular}{|c|c|c|c|c|c|}
\hline \multicolumn{2}{|c|}{ Variabel } & Koefisien & Std. Error & t-Statistic & Prob. \\
\hline \multicolumn{2}{|c|}{ M1 } & 0.036844 & 0.014907 & 2.471593 & $0.0138 *$ \\
\hline \multicolumn{2}{|c|}{ M2 } & 0.039203 & 0.015143 & 2.588755 & $0.0099 *$ \\
\hline \multicolumn{2}{|c|}{ M3 } & 0.010987 & 0.011188 & 0.982081 & 0.3266 \\
\hline F test & $=18,935$ & & & & \\
\hline Sig. F test & $=0,000$ & & & & \\
\hline R Square & $=0,2005$ & & & & \\
\hline Adjusted R & $=0,1899$ & & & & \\
\hline
\end{tabular}

Hasil pengujian moderasi lainnya menunjukkan bahwa keahlian akuntansi memoderasi (M2) hubungan antara keterlibatan dewan komisaris dalam komite remunerasi (BCRC) terhadap manajemen laba dengan probabilitas 0,0099 yang berarti lebih kecil dari nilai alpha 0,05, dengan nilai koefisien sebesar 0,039203. Dengan demikian dapat disimpulkan bahwa hipotesis kelima $\left(\mathrm{H}_{5}\right)$ dapat diterima. Keahlian akuntansi memoderasi hubungan antara keterlibatan dewan komisaris dalam komite remunerasi terhadap manajemen laba. Hasil ini sejalan dengan studi Dwiharyadi (2017) yang menemukan bahwa anggota dewan komisaris yang memiliki keahlian akuntansi berpengaruh terhadap manajemen laba. Jadi keahlian akuntansi dewan komisaris yang terlibat dalam komite remunerasi dapat mengurangi tingkat manajemen laba perusahaan. Dewan komisaris yang terlibat dalam komite remunerasi sekaligus mempunyai keahlian di bidang akuntansi juga mengurangi tingkat praktik manajemen laba (Al-absy, Nor, \& Ku 2019). Meskipun komite remunerasi ini tidak mengatur masalah pelaporan keuangan perusahaan, namun peran serta dewan komisaris yang memiliki keahlian akuntansi sangat efektif dalam mitigasi manajemen laba. Komite remunerasi ini mengatur pembagian remunerasi di perusahaan (Ahmad et al., 2018), jadi keahlian akuntansi yang dimiliki dewan komisaris secara efektif mampu membatasi secara langsung praktik manajemen laba.

Hasil pengujian moderasi lainnya menunjukkan keahlian akuntansi tidak signifikan dalam memoderasi (M3) hubungan antara dewan komisaris dalam komite audit (BCAC) terhadap manajemen laba dengan probabilitas 0,3266 yang berarti lebih besar dari nilai alpha 0,05, dengan nilai koefisien sebesar 0,010987. Dengan demikian dapat disimpulkan bahwa hipotesis keenam $\left(\mathrm{H}_{6}\right)$ ditolak. Hal ini berarti keahlian akuntansi tidak memoderasi secara signifikan hubungan antara komite audit dan manajemen laba. Namun demikian, hasil penelitian sebelumnya menyatakan bahwa keahlian akuntansi anggota dewan komisaris berpengaruh negatif terhadap manajemen laba perusahaan (Dwiharyadi, 2017). Hal ini karena komite audit berperan penting dalam terwujudnya good corporate governance (Utama, 2004). Komite audit berperan sebagai pengawas dalam manajemen laba yang dilakukan oleh perusahaan (Susanto, 2016). Menurut penelitian Xie, Davidson, \& Dadalt (2003), komite audit menjadi faktor penting dalam membatasi kecenderungan 
praktik manajemen laba, apalagi yang memiliki keahlian akuntansi di dalamnya. Hasil penelitian ini menyatakan bahwa dewan komisaris yang memiliki keahlian akuntansi dan terlibat dalam komite audit tidak berpengaruh signifikan terhadap manajemen laba, karena komite audit tetap menjalankan tugas sepenuhnya untuk pengawasan dalam pelaporan keuangan perusahaan.

\section{Kesimpulan, Implikasi dan Keterbatasan}

Hasil penelitian ini menyatakan bahwa dewan komisaris yang merangkap sebagai komite nominasi akan meningkatkan kemungkinan terjadinya praktik manajemen laba pada perusahaan. Begitu pula dengan dewan komisaris yang terlibat dalam komite audit juga akan meningkatkan praktik manajemen laba dalam perusahaan. Hasil penelitian lainnya menyatakan bahwa keahlian akuntansi dewan komisaris dapat memoderasi hubungan antara keterlibatan dewan komisaris dalam komite nominasi dan komite remunerasi terhadap praktik manajemen laba. Temuan penelitian ini mengimplikasikan bahwa dewan komisaris diharapkan memiliki peran dalam meningkatkan kualitas laba dalam perusahaan dengan cara membatasi tingkat manajemen laba. Apabila dewan komisaris terlibat dalam komite nominasi dan komite remunerasi, maka akan efektif dalam mengurangi terjadinya praktik manajemen laba. Namun demikian, dewan komisaris yang memiliki keahlian akuntansi sekaligus terlibat dalam komite audit tidak berpengaruh terhadap manajemen laba karena fungsi pengawasan komite audit hanya untuk memenuhi peraturan yang berlaku saja akibat dominasi dewan komisaris yang terlibat di dalamnya. Penelitian ini terbatas hanya menggunakan sektor manufaktur sebagai sampel penelitian. Penelitian mendatang dapat memperluas sampel penelitian dengan membandingkan sektor yang berbeda, seperti sektor keuangan, karena memiliki karakteristik akrual yang berbeda dalam mengukur manajemen laba.

\section{Daftar Pustaka}

Absy, Mujeeb Saif Mohsen Al, Ku Nor, \& Izah Ku. (2019). Board Chairmen's s Involvement in the Nomination and Remuneration Committees and Earnings Management Board Chairmen's Involvement in the Nomination and Remuneration. Australasian Accounting, Business and Finance Journal, 12(4), 60-76. https://doi.org/10.14453/aabfj.v12i4.5.

Adi, I Putu, \& Surya Lesmana. (2017). Pengaruh Manajemen Laba Pada Nilai Perusahaan Manufaktur Yang Terdaftar Di Bursa Efek Indonesia Tahun 2012-2015. E-Jurnal Akuntansi Universitas Udayana, 19, 1060-87.

Ahmad, Mohammad, Abu Zraiq, Faudziah Hanim, \& Bt Fadzil. (2018). The Impact of Nomination and Remuneration Committee on Corporate Financial Performance. Academy of Accounting and Financial Studies Journal, 22 (3), 1-6.

Aji, Bimo Bayu. (2012). Pengaruh Corporate Governance Terhadap Manajemen Laba Pada Perusahaan Manufaktur Di Bursa Efek Indonesia. Ekonomika, Fakultas Bisnis, Diponegoro, Universitas.

Al-absy, Mujeeb Saif Mohsen, Ku Nor, \& Izah Ku. (2019). Audit Committee Chairman Characteristics and Earnings Management. Asia-Pacific Journal of Business Administration, 11(4), 339-370. https://doi.org/10.1108/APJBA-10-2018-0188. 
Al-absy,Ku Nor, \& Izah Ku. (2017). Board Chairmen's Involvement in Audit Committees and Earnings Management Practices. SSRN Electronic Journal 12. https://doi.org/10.2139/ssrn.3063845.

Al-dhamari, Redhwan. (2020). Modeling the Impact of Audit / Remuneration Committee Overlap on Debtholders 'Perceptions of Accounting Information Quality: The Role of CEO Power. International Journal of Finance and Economics 10, 1-23. https://doi.org/10.1002/ijfe.2304.

Al-hadrami, Abdullah, Ahmad Rafiki, \& Adel Sarea. (2020). The Impact of an Audit Committee's Committee Investment Decision : A Study in Bahrain. Asian Journal of Accounting Research 5(2), 299-313. https://doi.org/10.1108/AJAR-02-2020-0008

Al-sayani, Yahya Mohammed, Mohamad Mohamad Nor Naimi, \& Noor Afza. (2020). The Influence of Audit Committee Characteristics on Impression Management in Chairman Statement : Evidence from Malaysia. Cogent Business \& Management, 7(1) https://doi.org/10.1080/23311975.2020.1774250.

Azis, Ilhamda. (2020). Motivasi Manajer Dalam Melakukan Manajemen Laba Dikaji Dalam Pandangan Islam. Jurnal Riset dan Aplikasi: Akuntansi dan Manajemen 4 (4), 319-30.

Beekun, Rafik Issa. (2004). Etika Bisnis Islami. Pustaka Pelajar.

Boshkoska, Meri. (2015). The Agency Problem: Measures for Its Overcoming. International Journal of Business and Management, 10 (1), 204-9. https://doi.org/10.5539/ijbm.v10n1p204.)

Bouaziz, Dhouha. (2020). CEO Characteristics and Earnings Management: Empirical Evidence from France, Journal of Financial Reporting and Accounting, 18 (1), 77110. https://doi.org/10.1108/JFRA-01-2019-0008.

Chandrasegaram, Reinushini, Mohamed Razeef Rahimansa, \& Suraya K A Rahman. 2013. Impact of Audit Committee Characteristics on Earnings Management in Malaysian Public Listed Companies, International Journal of Finance and Accounting, 2(2), 114-19. https://doi.org/10.5923/j.ijfa.20130202.11.

Chaudhry, Naveed Iqbal, Muhammad Azam Roomi, \& Iqra Aftab. (2020). Impact of Expertise of Audit Committee Chair and Nomination Committee Chair on Financial Performance. Corporate Governance: The International Journal of Business in Society, 20(4), 621-38. https://doi.org/10.1108/CG-01-2020-0017.

Dwiharyadi, Anda. (2017). Pengaruh Keahlian Akuntansi Dan Keuangan Komite Audit Dan Dewan Komisaris Terhadap Manajemen Laba. Politeknik Negeri Padang, 14 (1), 75-93.

Ghozali, Imam. 2011. Aplikasi Multivariate Dengan Program IBM SPSS 19. Semarang: Badan Penerbit Universitas Diponegoro.

Hariani, Ulfah, Nur Diana, \& M Cholid Mawardi. (2020). Pengaruh Keahlian Akuntansi Dan Keahlian Keuangan Pada Komite Audit Dan Dewan Komisaris Terhadap Manajemen Laba. Fakultas Ekonomi Dan Bisnis Universitas Islam Malang, 09 (04), $46-62$.

Heikal, Mohd. (2014). Influence Analysis of Return on Assets ( ROA ), Return on Equity ( ROE ), Net Profit Margin ( NPM ), Debt To Equity Ratio ( DER ), and Current Ratio 
( CR ), Against Corporate Profit Growth In Automotive In Indonesia Stock Exchange, International Journal of Academic Research in Business and Social Sciences 4(12), 101-14. DOI: 10.6007/IJARBSS/v4-i12/1331

Hidayat, Anwar. (2016). Pengertian Multikolinearitas Dan Dampaknya. 2016. http://www.statistikian.com/2016/11/multikolinearitas.html.

Kanapathippillai, Sutharson, Shireenjit K Johl, \& Graeme Wines. (2016). Remuneration Committee Effectiveness and Narrative Remuneration Disclosure. Pacific-Basin Finance Journal https://doi.org/10.1016/j.pacfin.2016.02.006.

Kharashgah, Khaled Ahmad, Noor Afza, Binti Amran, \& Rokiah Binti Ishak. (2019). The Impact of Audit Committee Characteristics on Real Earnings Management : Evidence from Jordan. International Journal of Academic Research in Accounting, Finance and Management Sciences, 9 (4), 84-97. https://doi.org/10.6007/IJARAFMS/v9-i4/6699.

Khosheghbal, Marzieh, Ali Amiri, \& Ali Homayoon. (2017). Role of Audit Committees and Board of Directors in Reducing Earning Management of Companies Listed in Tehran Stock Exchange. International Journal of Economics and Financial Issues, 7 (6), 147-53.

Lestari, Eka, \& Murtanto. (2017). Pengaruh Efektivitas Dewan Komisaris Dan Komite Audit, Struktur Kepemilikan, Kualitas Audit Terhadap Manajeme Laba. Jurnal Media Riset Akuntansi, Auditing \& Informasi Universitas Trisakti Indonesia, 17 (2), 97-116.

Lin, Jerry W, \& Mark I Hwang. (2010). Audit Quality, Corporate Governance, and Earnings Management: A Meta-Analysis, International Journal of Auditing 14(1), 57-77. https://doi.org/10.1111/j.1099-1123.2009.00403.x.

Liu, Jinghui, Kate Harris, \& Noraini Omar. (2013). Board Committees and Earnings Management, Corporate Board: role, duties and composition, 9(1), 6-17. https://doi.org/10.22495/cbv9ilart.

Manuel, Juan, \& San Martin. (2018). The Effect of Ownership Composition on Earnings Management: Evidence for the Mexican Stock Exchange, Journal of Economics, Finance and Administrative Science, 23(46), 289-305. https://doi.org/10.1108/JEFAS-01-2017-0011.

Marzuqi, Ahmad Yusuf, \& Achmad Badarudin Latif. (2010). Manajemen Laba Dalam Tinjauan Etika Bisnis Islam, Jurnal Dinamika Ekonomi dan Bisnis 7(1), 1-22.

Muliasari, Indah. (2006). Manajemen Laba Dalam Sudut Pandang Etika Bisnis Islam, Jurnal Akuntansi dan Keuangan Islam 2(2), 157-182.

Murwaningsari, Etty. (2006). Responsibilities Dan Corporate Financial Performance Dalam Satu Continuum, Jurnal Akuntansi dan Keuangan. 11(1), 30-41

Panda, Brahmadev, \& N M Leepsa. (2017). Agency Theory: Review of Theory and Evidence on Problems and Perspectives. Indian Journal of Corporate Governance 10(1), 74-95. https://doi.org/10.1177/0974686217701467.

Rahman, Rashidah Abdul. (2014). Board, Audit Committee, Culture and Earnings Management: Malaysian Evidence. Managerial Auditing Journal 21(7), 783-804. https://doi.org/10.1108/02686900610680549.

Ramadhan, Kemal Cahya. (2016). Pengaruh Keanggotaan Wanita Dalam Struktur 
Corporate Governance Serta Keberadaan Komite Nominasi Dan Remunerasi Terhadap Manajemen Laba. Undergraduate thesis, Fakultas Ekonomika dan Bisnis Universitas Diponegoro.

Reguera-alvarado, Nuria, Pilar De Fuentes, \& Joaquina Laffarga. (2019). Do Auditors Mitigate Earnings Management during Economic Crisis ?. Revista de Contabilidad 22 (1),6-20. DOI: 10.6018/rcsar.22.1.354271

Saona, Paolo.(2019). How Do the Ownership Structure and Board of Directors ' Features Impact Earnings Management? The Spanish Case. Journal Finance Management Accounting, 6, 1-36. https://doi.org/10.1111/jifm.12114.

Sari, Ardiana Luthvita. (2017). Karakteristik Perusahaan, Tata Kelola Perusahaan Dan Manajemen Laba. Universitas Katolik Soegijapranata, 15 (2), 229-45.

Shubita, Mohammad Fawzi. (2020). Earnings Management and Corporate Governance Evidence from Jordanian Banks, International Journal of Recent Technology and Engineering 8(5), 1724-1731. https://doi.org/10.35940/ijrte.E4941.018520.

Sunardi. (2018). The Effect of Earnings Management on Firm Value before and When IFRS Implementation, Moderated Life Cycle Company. Journal of Business and Economics Universitas Muhammadiyah Palembang, 9 (3), 275-85. https://doi.org/10.15341/jbe(2155-7950)/03.09.2018/006.

Susanto, Yulius Kurnia. (2016). The Effect of Audit Committees and Corporate Governance on Earnings Management: Evidence From Indonesia Manufacturing Industry. International Journal of Business, Economics, and Law, 10 (1), 32-37.

Syahirah, Norfarah, \& Binti Mohd. (2017). Board of Directors Characteristics and Earnings Management of Family-Owned Companies. International Journal of Accounting \& Business Management, 5 (2), 68-83.

Utama, Marta. (2004). Komite Audit, Good Corporate Governance Dan Pengungkapan Informasi, Jurnal Akuntansi dan Keuangan Indonesia 1, 61-79.

Wasan, Pratibha. (2020). Corporate Governance Factors as Predictors of Earnings Management. Journal of General Management, $45 \quad$ (2), 71-92. https://doi.org/10.1177/0306307019872304.

Xie, Biao, Wallace N Davidson, \& Peter J Dadalt. (2003). Earnings Management and Corporate Governance: The Role of the Board and the Audit Committee. Journal of Corporate Finance, 9(3) , 295-316.

Zubeltzu-jaka, Eugenio, Igor Alvarez-etxeberria, \& Eduardo Ortas. (2020). The Effect of the Size of the Board of Directors on Corporate Social Performance: A Meta-Analytic Approach, Corporate Social Responsibility and Environmental Management 27 (3), 1361-1374. https://doi.org/10.1002/csr.1889 